\title{
Perception of healthy eating among adults participating in the Eat-Mot survey in
} Brazil

Percepção de alimentação saudável entre adultos participantes da pesquisa Eat-Mot no Brasil Percepción de la alimentación saludable entre los adultos que participan en la encuesta Eat-Mot en Brasil

Vanessa Alves Ferreira

ORCID: https://orcid.org/0000-0003-0417-8490 Universidade Federal de Minas Gerais, Brazil

E-mail: vanessa.nutr@gmail.com

Aline Cristine Souza Lopes

ORCID: https://orcid.org/0000-0001-9782-2606 Universidade Federal de Minas Gerais, Brazil

E-mail: alinelopesenf@gmail.com

Raquel de Pinho Ferreira Guiné

ORCID: https://orcid.org/0000-0003-0595-6805 Instituto Politécnico de Viseu, Portugal

E-mail: raquelguine@esav.ipv.pt

Milton Cosme Ribeiro

ORCID: https://orcid.org/0000-0003-4522-9047

Universidade Federal de Minas Gerais, Brazil

E-mail: miltoncribeiro@gmail.com

Ivy Scorzi Cazelli Pires

ORCID: https://orcid.org/0000-0001-8103-4488

Universidade Federal dos Vales do Jequitinhonha e Mucuri, Brazil

E-mail: ivycazelli1@gmail.com

Lucilene Soares Miranda

ORCID: https://orcid.org/0000-0003-0328-6836

Universidade Federal dos Vales do Jequitinhonha e Mucuri, Brazil

E-mail: lucisoares1@hotmail.com

Rosana Magalhães

ORCID: https://orcid.org/0000-0003-3831-8877

Fundação Oswaldo Cruz, Brazil

E-mail: rosana@ensp.fiocruz.br

\begin{abstract}
The purpose was to verify the association between sociodemographic and health characteristics with the perception of healthy eating among Brazilian participating in the international study Eat-Mot. The perception of healthy eating was investigated by frequency categorized into: never/rarely/sometimes and most of the times/always. Ordinal logistic regression was used to calculate "odds ratio" to verify the relationship between sociodemographic and health variables with the perception of healthy eating. Six hundred and sixty individuals participated, most of them women $(74,7 \%)$ who have completed higher education or ongoing $(77,6 \%)$. A good number of the interviewees perceived their diet as healthy $(49,3 \%)$. In multivariate analysis, it was noted that there was a negative association between the perception of healthy eating with: be male ( $\mathrm{OR}=0,45$; IC95\%: $0,31-0,64)$; have less education (high school: $\mathrm{OR}=0,51$; IC95\%: 0,35-0,74 and elementary school: OR=0,11; IC95\%: 0,03-0,42); less practice of physical activity (>3 times/week: OR=0,40; IC95\%: 0,25-0,63, 2-3 times/week: OR=0,29; IC95\%: 0,16-0,52; <once/week: OR=0,24; IC95\%: 0,14-0,41; and never: OR=0,13; IC95\%: 0,08-0,22) and higher body mass index (OR=0,94; IC95\%: 0,91$0,97)$. The results showed the relevance of studies of this nature to encourage the adoption of multiple healthy behaviors, with special attention to the less educated male group.
\end{abstract}

Keywords: Food habits; Feeding behavior; Health promotion; Public policy.

\section{Resumo}

O objetivo foi verificar a associação entre características sociodemográficas e de saúde com a percepção de alimentação saudável entre brasileiros participantes do estudo internacional Eat-Mot. A percepção da alimentação saudável foi investigada pela frequência categorizada em: nunca / raramente / às vezes e na maioria das vezes / sempre. A regressão logística ordinal foi utilizada para calcular o "odds ratio" para verificar a relação entre as 
Research, Society and Development, v. 10, n. 2, e50110212601, 2021

(CC BY 4.0) | ISSN 2525-3409 | DOI: http://dx.doi.org/10.33448/rsd-v10i2.12601

variáveis sociodemográficas e de saúde com a percepção de alimentação saudável. Participaram seiscentos e sessenta indivíduos, a maioria mulheres (74,7\%) com ensino superior completo ou em andamento (77,6\%). Boa parte dos entrevistados percebeu sua alimentação como saudável (49,3\%). Na análise multivariada, percebeu-se que houve associação negativa entre a percepção de alimentação saudável com: ser do sexo masculino $(\mathrm{OR}=0,45 ; \mathrm{IC} 95 \%$ : 0,31 0,64); ter menor escolaridade (ensino médio: $\mathrm{OR}=0,51$; IC95\%: 0,35-0,74 e ensino fundamental: OR = 0,11; IC95\%: 0,03-0,42); menos prática de atividade física (> 3 vezes / semana: OR = 0,40; IC95\%: 0,25-0,63, 2-3 vezes / semana: OR = 0,29; IC95\%: 0,16-0 , 52; <uma vez / semana: OR = 0,24; IC95\%: 0,14-0,41; e nunca: OR =0,13; IC95\%: 0,080,22) e índice de massa corporal superior (OR =0,94; IC95\%: 0,91-0,97). Os resultados mostraram a relevância de estudos desta natureza para estimular a adoção de múltiplos comportamentos saudáveis, com atenção especial para o grupo masculino menos escolarizado.

Palavras-chave: Hábitos alimentares; Comportamento alimentar; Promoção de saúde; Políticas públicas.

\section{Resumen}

El propósito fue verificar la asociación entre características sociodemográficas y de salud con la percepción de alimentación saludable entre los brasileños participantes del estudio internacional Eat-Mot. La percepción de una alimentación saludable se investigó por frecuencia categorizada en: nunca / rara vez / a veces y la mayoría de las veces / siempre. Se utilizó regresión logística ordinal para calcular la "razón de posibilidades" para verificar la relación entre las variables sociodemográficas y de salud con la percepción de una alimentación saludable. Participaron seiscientas sesenta personas, la mayoría mujeres $(74,7 \%)$ con estudios superiores o en curso (77,6\%). Un buen número de los entrevistados percibió su dieta como saludable (49,3\%). En el análisis multivariado se observó que existía una asociación negativa entre la percepción de alimentación saludable con: ser hombre $(\mathrm{OR}=0,45$; IC95\%: 0,31-0,64); tener menos educación (secundaria: OR = 0,51; IC95\%: 0,35-0,74 y primaria: OR = 0,11; IC95\%: 0,03-0,42); menor práctica de actividad física (> 3 veces / semana: OR =0,40; IC95\%: 0,25-0,63, 2-3 veces / semana: OR = 0,29; IC95\%: 0,16-0 , 52; <una vez por semana: OR = 0,24; IC95\%: 0,14-0,41; y nunca: OR =0,13; IC95\%: 0,08-0,22) e índice de masa corporal más alto (OR = 0,94; IC95\%: 0,91-0,97). Los resultados mostraron la relevancia de estudios de esta naturaleza para incentivar la adopción de múltiples conductas saludables, con especial atención al grupo masculino menos educado.

Palabras clave: Hábitos alimenticios; Comportamiento alimentario; Promoción de la salud; Politica social.

\section{Introduction}

In contemporary western societies the choice for foods considered unhealthy with high caloric density is growing due to the large amount of sugars, fats, sodium and other additives. This profile has contributed to the epidemic burden of chronic diseases, including obesity, ischemic heart disease and stroke (Who, 2018; 2020). On the other hand, it is observed that there is a growing trend of consumers increasingly aware of their alimentary choices. In general, these consumers are more demanding, and they value the origin as well as, the food quality as they consider their impact on their health and environment, opting for a healthier and more environmentally sustainable diet (Bartels and Hoogendam, 2011; Assif et al, 2018). This contradictory scenario reveals that food choices are complex, dynamics and permeated by multiple factors - socioeconomic, environmental, psychological and cultural. They involve everyday decisions influenced by environmental conditions, as well as, for elements of sociocultural and symbolic nature, that contribute to determine the construction of a healthy diet or not (Rozin, 1980; Lindemann et al, 2016; Hoek et al, 2017).

In Brazil, studies (Jaime, 2015; Machado et al., 2020) show a positive prevalence regarding the self-perception of healthy eating. In general, older individuals, with higher income and considered sufficiently active showed a higher frequency of positive self-perception of their food. Among the difficulties with this perception were: adulthood, lower income, greater number of self-reported chronic diseases, lack of dietary guidance and habit of not reading food labels. Among those who had difficulties, the reasons mentioned were: high cost of healthy food, low adherence to change, need to avoid unhealthy food, lack of time and not enough knowledge.

Studies about the perception of food and factors associated to this perception are so important because they allow us to understand how individuals perceive their food and the factors that influence this perception. These researches can contribute to the design of health interventions, that consider the individual as the protagonist e active subject of their change 
processes. In this sense, this study aimed to verify the association between sociodemographic and health characteristics with the perception of healthy eating among Brazilians participating in a multicentric study conducted in sixteen countries of Europe, Africa e Americas (Ferrão et al., 2019).

\section{Methods}

\subsection{Study Design and Sample}

A cross-sectional study was carried out with data from international multicentric research entitled: "Psychosocial Motivations associated with Food Choices" (EAT-MOT) which involved the following countries: Argentina, Brazil, Croatia, Egypt, Greece, Hungary, Italy, Latvia, Lithuania, Netherlands, Poland, Portugal, Serbia e Slovenia (Pereira et al., 2018).

The EAT-MOT sample is a non-probabilistic sample, and in this study, the data of Brazilian participants aged 18 or over were analyzed, totalizing 660 individuals.

\subsection{Data Collect}

The data collect took place in the years 2017 and 2018, and it was based on the self-completed questionnaire available in online format.

\subsection{Explanatory Variables of Interest}

Sociodemographic and health data were investigated as explanatory variables of interest. The analysed socidemographic data were: age (years), gender (female and male), civil status (single; separated/divorced/widowed; married/stable union), schooling (graduation; high scool; elementary school), professional occupation (employed; student; studying and working; retired; unemployed), residence situation (urban and rural) and responsable for the purchase of food at home (yes/no).

The health profile consisted of investigating information on referred morbidity: diabetes and arterial hypertension (yes/no); nutritional status assessed by the Body Mass Index (BMI), calculating from self-reported weight and height measurements; frequency of physical activity (+3 times/week; 2-3 times/week; Once/week; Less than once/week; Never); and daily time (in hours) watching television or using the computer.

\subsection{Outcome Variable}

The study outcome variable was the perception of food as healthy, assessed from the question: "How often do you believe you practice a balanced/healthy diet?". With dichotomized answer in yes (most of the times; always) and no (never; rarely; sometimes).

\subsection{Data Analysis}

The analysis were made in the software Stata (Stata Corporation, College Station, and Texas) version 14.0. The descriptive analysis of the variables was made by calculating the prevalence and $95 \%$ confidence interval in order to characterize the sample, including the calculation of frequency distribution, measures of central tendency (median) and dispersion (interquatylic range).

Pearson Chi-square statistical tests for categorical variables and Kruskall-Wallis for continuous variables were performed to describe the sociodemographic and health characteristics according to the perception of healthy eating. 
Research, Society and Development, v. 10, n. 2, e50110212601, 2021

(CC BY 4.0) | ISSN 2525-3409 | DOI: http://dx.doi.org/10.33448/rsd-v10i2.12601

To identify the association between sociodemographic and health characteristics with the perception of healthy eating, the Odds Ratio (in Brazil, Razão de Chances) values were used, obtained from the Ordinal Logistic Regression.

\subsection{Ethical issues}

The participation in this research was voluntary and carried out only for individuals aged 18 years or older. The Free Informed Consent Form (in Brazil, TCLE) was obtained for all participants and both secrecy and confidentiality were ensured. The data collect happened between the years 2017 and 2018 in Brazilian population through an online questionnaire. The study was approved by the Research Ethics Committee (CEP) of the Polytechnic Institute of Viseu (IPV) under the reference number $04 / 2017$.

\section{Results and Discussion}

In Brazil, 660 individuals over the age of 18 participated in the study. The sociodemographic profile of the interviewees revealed that the sample consisted mostly by women $(74,7 \%)$, single individuals $(52,1 \%)$, with higher education $(77,6 \%)$ and with a median age of 32 years (Table 1). Most worked or studied. Regarding health characteristics, the prevalence of arterial hypertension and diabetes were, respectively 7,0\% and 1,7\%. Now the BMI median was $23,4 \mathrm{~kg} / \mathrm{m}^{2}$, in the eutrophic range. In relation to the practice of physical activity, it was found that, $17,4 \%$ of the interviewees regularly perfomed physical activities (3 times a week) (Table 1).

Table 1. Sociodemographic and health characteristics according to the perception of healthy eating. EAMOT Study (Brazil). 2017-2018.

\begin{tabular}{|c|c|c|c|c|}
\hline \multirow[b]{2}{*}{ Variable } & \multirow[b]{2}{*}{ Total $(\mathrm{N}=660)$} & \multicolumn{2}{|c|}{ Perception of balances/healthy eating } & \multirow[b]{2}{*}{ p-value } \\
\hline & & $\begin{array}{c}\text { Yes } \\
(n=372 ; 56.4 \%)\end{array}$ & $\begin{array}{c}\text { No } \\
(\mathrm{n}=288 ; 43.6 \%)\end{array}$ & \\
\hline Age (years) (median, P25-P75) & $32(27-40)$ & $33(29-42)$ & $31(25-38)$ & $\mathbf{0 . 0 0 1}^{1}$ \\
\hline \multicolumn{5}{|l|}{ Gender (\%) } \\
\hline Male & 25.3 & 19.3 & 33.0 & \multirow{2}{*}{$<0.001^{2}$} \\
\hline Female & 74.7 & 80.6 & 67.0 & \\
\hline \multicolumn{5}{|l|}{ Schooling (\%) } \\
\hline Graduation & 77.6 & 84.9 & 68.1 & \multirow{3}{*}{$<0.001^{2}$} \\
\hline High School & 21.6 & 14.8 & 30.6 & \\
\hline Elementary School & 0.8 & 0.3 & 1.4 & \\
\hline \multicolumn{5}{|l|}{ Professional Activity (\%) } \\
\hline Employed & 60.4 & 63.2 & 56.9 & \multirow{5}{*}{$0.096^{2}$} \\
\hline Student & 16.1 & 15.9 & 16.3 & \\
\hline Studying and working & 12.3 & 10.7 & 14.2 & \\
\hline Retired & 3.5 & 4.3 & 2.4 & \\
\hline Unemployed & 7.7 & 5.9 & 10.1 & \\
\hline \multicolumn{5}{|l|}{ Civil status (\%) } \\
\hline Single & 52.1 & 48.7 & 56.6 & \multirow{3}{*}{$0.128^{2}$} \\
\hline Separated/divorced/widowed & 7.7 & 8.3 & 6.9 & \\
\hline Married/stable union & 40.2 & 43.0 & 36.5 & \\
\hline
\end{tabular}


Research, Society and Development, v. 10, n. 2, e50110212601, 2021

(CC BY 4.0) | ISSN 2525-3409 | DOI: http://dx.doi.org/10.33448/rsd-v10i2.12601

Residence situation (\%)

Urban

98.2

1.8

99.2

96.9

3.1

$0.027^{2}$

Rural

0.8

Diabetes (\%)

No

98.3

1.7

98.7

97.9

2.1

$0.462^{2}$

Arterial Hypertension (\%)

No

93.0

91.9

94.4

5.6

$0.209^{2}$

Yes

8.1

24.2(21.5-28.3)

$0.001^{1}$

BMI $\left(\mathbf{k g} / \mathbf{m}^{2}\right)$ (median, P25-P75)

+3 times/week

2-3 times/semana

17.4

15.6

9.0

1 time/week

34.4

13.7

29.5

Less than once/week

9.8

8.6

11.5

$<0.001^{2}$

Never

16.2

38.2

19.4

22.2

23.9

30.6

Source: Research Data (2017/2019).

In relation to having a healthy diet, a good number of the interviewees reported yes in most of the times $(49,3 \%)$; and then sometimes $(34,2 \%)$, rarely $(7,3 \%)$, always $(6,7 \%)$ and never $(2,5 \%)$.

In multivariate analysis having as an outcome the perception of healthy eating, a negative association was observed with the following variables: male gender (OR =0,45; IC95\%: 0,31-0,64); lower level of education (high school: OR=0,51; IC95\%: 0,35-0,74 e elementary school: OR=0,11; IC95\%: 0,03-0,42), lower level of physical activity (>3 times/week: OR=0,40; IC95\%:0,25-0,63; 2-3 times/week: OR=0,29; IC95\%:0,16-0,52; <once/week: OR=0,24; IC95\%: 0,14-0,41; and never: $\mathrm{OR}=0,13$; IC95\%: 0,08-0,22) and higher BMI value (OR=0,94; IC95\%: 0,91-0,97) (Table 2). 
Research, Society and Development, v. 10, n. 2, e50110212601, 2021

(CC BY 4.0) | ISSN 2525-3409 | DOI: http://dx.doi.org/10.33448/rsd-v10i2.12601

Table 2. Odds ratio stimulated by ordinal logistic regression to analyze the relationship between sociodemographic and health characteristics with the perception of healthy eating. EAMOT Study (Brazil). 2017-2018.

\begin{tabular}{|c|c|c|}
\hline Variable & OR $_{\text {Bivariate_Analysis }}[\mathrm{IC} 95 \%]$ & OR $_{\text {Multivariate_Analysis [IC95\%] }}$ \\
\hline Age (years) & $1,02 *[1,01-1,04]$ & $1,02[1,00-1,04]$ \\
\hline \multicolumn{3}{|l|}{ Gender } \\
\hline Female & Ref. & Ref. \\
\hline Male & $0,50 *[0,36-0,70]$ & $0,45^{*}[0,31-0,64]$ \\
\hline \multicolumn{3}{|l|}{ Schooling } \\
\hline Graduation & Ref. & Ref. \\
\hline High School & $0,42 *[0,29-0,60]$ & $0,51 *[0,35-0,74]$ \\
\hline Elementary School & $0,11 *[0,03-0,36]$ & $0,11 *[0,03-0,42]$ \\
\hline \multicolumn{3}{|l|}{ Professional activity } \\
\hline Employed & Ref. & - \\
\hline Student & $0,86[0,58-1,28]$ & - \\
\hline Study and work & $0,72[0,46-1,12]$ & - \\
\hline Retired & $1,87[0,79-4,44]$ & - \\
\hline Unemployed & $0,58[0,33-1,00]$ & - \\
\hline \multicolumn{3}{|l|}{ Civil status } \\
\hline Single & Ref. & Ref. \\
\hline Separated/divorced/widowed & $1,49[0,85-2,59]$ & $1,27[0,66-2,46]$ \\
\hline Married/living together & $1,39 *[1,02-1,89]$ & $1,21[0,84-1,74]$ \\
\hline \multicolumn{3}{|l|}{ Residence situation } \\
\hline Urban & Ref. & Ref. \\
\hline Suburban & $0,47[0,13-1,67]$ & $0,38[0,10-1,45]$ \\
\hline Rural & $0,26 *[0,09-0,76]$ & $0,51[0,18-1,48]$ \\
\hline \multicolumn{3}{|l|}{ Responsible for purchasing food } \\
\hline Yes & Ref. & Ref. \\
\hline No & $0,68 *[0,47-0,98]$ & $0,88[0,59-1,32]$ \\
\hline \multicolumn{3}{|l|}{ Practice of physical activity } \\
\hline +3 times/week & Ref. & Ref. \\
\hline 2-3 times/week & $0,52 *[0,34-0,82]$ & $0,40 *[0,25-0,63]$ \\
\hline 1 time/week & $0,37 *[0,21-0,65]$ & $0,29 *[0,16-0,52]$ \\
\hline Less than once/week & $0,28 *[0,17-0,47]$ & $0,24 *[0,14-0,41]$ \\
\hline Never & $0,16^{*}[0,10-0,27]$ & $0,13 *[0,08-0,22]$ \\
\hline Daily time (hours) in TV/computer & $0,97[0,94-1,00]$ & - \\
\hline BMI $\left(\mathbf{k g} / \mathbf{m}^{2}\right)$ & $0.93 *[0.91-0.96]$ & $0,94 *[0,91-0,97]$ \\
\hline \multicolumn{3}{|l|}{ Cardiovascular Disease } \\
\hline No & Ref. & - \\
\hline Yes & $1,35[0,18-10,40]$ & - \\
\hline \multicolumn{3}{|l|}{ Diabetes } \\
\hline No & Ref. & - \\
\hline Yes & $0,77[0,27-2,18]$ & - \\
\hline \multicolumn{3}{|l|}{ High Cholesterol } \\
\hline No & Ref. & - \\
\hline Yes & $1,10[0,57-2,14]$ & - \\
\hline
\end{tabular}




\section{Arterial Hypertension}

No Ref.

Yes $1,12[0,63-1,98]$

Notes: OR $=$ odds ratio. $95 \% \mathrm{CI}=95 \%$ confidence interval. Ref. $=$ Reference category. BMI = Body mass index. $*$ Significant for a pvalue of $5 \%$.

Source: Research Data (2017/2019).

The results of this study revealed that the perception of healthy eating showed striking differences between the genders, the level of education, the BMI and the practice of physical exercises. The women, especially university students who lived in an urban environment and had more schooling, they perceived their diet as being healthier, mainly due to their concern for health. The perception of nutrition is a strategy that seems to us to be essential to recognize the need to change the eating behavior of individuals in order to promote health (Guiné et al, 2020). A study made by Toledo, Abreu e Lopes (2013) that aimed to estimate the prevalence and factors associated with adherence to healthy lifestyles, including diet, showed that adherence was associated with the perception of having a healthy diet in addition to participation in public health promotion services.

According to Santos et al (2020), individuals who are more motivated by health to choose foods had a healthier diet. For the authors, information on the motivations for choosing foods can increase the effectiveness of educational interventions as well as adherence to good eating habits. The study by Tabassum e Jabir (2020), in turn, found that health awareness was the main psychological factor for the purchase of healthy foods, influencing the willingness of buyers to pay for the purchase of these products. The results of this study also showed that the most important demographic variables associated with the willingness to buy healthy foods were income and education. In fact, the educational level has been considered a factor capable of influencing healthy food choices, being an important component for educational actions. The study Lins et al. (2013) with Brazilian women showed that the consumption of healthy food gradually increased with the level of education of the participants. She concluded in her study that even in a low-income population, a higher level of education has a positive impact on healthy food choices. The same finding was evidenced in the study by Gombi-Vaca et al (2017) carried out with Brazilian families, which revealed that having higher education and income contributed to a greater consumption of healthier food at home. Many surveys in other countries also reveal that health-conscious individuals tend to buy more organic food (Irianto, 2015; Yadav and Patak, 2016; Nagaragy, 2020). The organic consumers are willing to pay an additional amount to these products due to their healthiness and less impact on the environment (Rahman et al., 2021).

Around half of the interviewees considered their diet to be healthy, confirming with national studies (Jaiime, 2015; Lindemann et al, 2016; Machado et al 2020). Nevertheless, in certain groups the chance of having a healthy diet was less, like among men, those with less education and practice of physical activity as well as, among individuals with higher BMI value. It is consensus in the literature that individuals with a better perception of health are more likely to take care of their general health, presenting healthier life behaviors (Reichert and Capilheira, 2012). In general, individuals with less education tend not to have enough perception of their nutrition, neither access to information nor health care (Machado et al 2020).

Internationally, there is an increasing recognition of the importance of health policies and actions aimed at promoting healthy eating (Who, 2018). Following this trend, the Brazilian government has, in recent years, intensified its public policies to promote adequate and healthy food. The Ministry of Health, through the Unified Health System (SUS), has been the main proponente of these actions, especially, in Primary Health Care. Since the 90's, the National Food and Nutrition Policy (Brasil, 1999) has aimed to improve the conditions of food, nutrition and health of the Brazilian population. The Policy was revised in 2012 (Brasil, 2012) and established three major action strategies: 1) the promotion of adequate and healthy 
Research, Society and Development, v. 10, n. 2, e50110212601, 2021

(CC BY 4.0) | ISSN 2525-3409 | DOI: http://dx.doi.org/10.33448/rsd-v10i2.12601

eating practices; 2) the food and nutrition surveillance and 3) the prevention and comprehensive care of diseases related to food and nutrition. Such strategies have been based on socio-environmental and individualized approaches aimed at changing health-related behaviors, including eating and physical activity practices, with the support of official publications, with emphasis on the Food Guide for the Brazilian population (Brasil, 2014;2016).

Possibly, the results of this study may reflect, to some extent, the effects of these actions over the past few years in Brazil. However, it's necessary to consider that the sample was built by a predominantly young, female and educated population, in which notably the sócio-cultural pressures related to the body, the beauty and health are more persuasive. Studies on the social construction of the body in Brazil reveal that at the end of hte 20th century and the beginning of the 21st century the cult of the body became a national obsession, and then turning to a lifestyle. The concern with health, which was once opposed to the disease, came to be confused with aesthetics and beauty. This new ethics in relation to the body, according to Baudrillard (2010), evokes the narcissistic, dietary, hygienic and therapeutic cult, including having a regulated and supervised diet to obtain/maintain this perfect body. This ideal of beauty has been relentless, especially in the female group. Thus, although the female body has been emancipated, it is still subjected to imperative aesthetic constraits (Goldenberg, 2002; 2004; Lipovetsky, 2002; Fischler e Masson, 2010). In this regard, for Bourdieu (1999), the male domination structure, constitutes women as symbolic objects, generating permanent body insecurity in the group. In this way, being feminine represents stereotypes of delicacy, submission, discretion and also, more recently, thinness.

However, it's interesting to notice new trends of behavior nowadays. Recent studies (Ilana et al., 2017; Costa et al, 2019). I revealed that young women have used social media as vehicles of communication and sociability in an attempt to share their daily experiences related to lifestyle. It is observed, for example, that through veganism, many of them make the transition from disconnecting the focus on body image to an emocional (empathetic), cognitive (knowledge of cruelty to animals and healthy food) and behavioral (diet and consumption choices) investment. In parallel, another experience in this regard has been observed in relation to motherhood, with greater reflection on the quality of food offered to the family and the option for healthier foods (Bastos et al., 2012).

Even so, it's not only women who suffer from social pressures related to body and beauty. According to Pierre Bourdieu (1999), there are pressures on both sides in the male-dominated relationship, in which men are also pressured to maintain socially constructed stereotypes related to strength, power, omnipotence and virility. This social imaginary that sees men as invulnerable beings ends up contributing to them taking less care and exposing themselves to risk situations. In this direction, studies (Eyken et al, 2009; Moura, 2014) in Brazil revealed that, men with less education, are more vulnerable to risk behaviors, including dependence of alcoholic drinks, smoking, physical inactivity, less healthy food consumption, negative self-assessment health conditions, as well as a higher frequency of overweight and chronic diseases. These risk behaviors contribute to the impact on group mortality. The overall mortality rate is higher in men when compared to women. It is estimated that, for every 3 deaths of Brazilians in the age group of 20 and 53 years, two are men. In Brazil, the main causes of death in the male group are diseases in the circulatory system, external causes and neoplasms, outcomes related to inadequate nutrition (Brasil, 2020).

Particularly, with regard to men's food, there are multiple elements operating in this dynamic, especially the socioeconomic and cultural ones. The contemporary phenomenon of gourmetization of food, for example, with the profusion of television programs, reveals, on the one hand, the historical male protagonism in the area of haute cuisine, but also a tendency of greater presence of men in domestic kitchens (Bauman, 2002). This is due to the increase in the number of mononuclear arrangements and the greater division in the life of the home. And it reveals the new contours of masculinities nowadays. At the same time, the medicalization of food ant the transformation of it into merchandise by a consumer society 
contributes to boost sales of nutricional and functional supplements in addition to resources associated with the increase in men's performance. Moreover, for certain segments, it grows the offer of products and services that aim to serve a male consumer market shaped according to its own aesthetic pattern and not necessarily healthy (Ferreira, 2011; Boaventura, 2012).

Studies on the theme of the male health in the country that are anchored in a socio-anthropological perspective, reveal important challenges to be overcome for health prevention and health prevention and promotion actions. These obstacles to subjective aspects such as feelings of shame or fear of being exposed to health professionals; work issues such as lack of time to participate in health actions and little resolutions to their demands (Gomes, 2011; Cavalcanti, 2014). There are still important gaps in health services that need to be overcome, including an adaptation of the structure to serve the male population; the development of promotion actions against the most frequent injuries among men and the training of health professionals to deal with this group, in particular. All these obstacles seem to reveal that the creation of the Men Health Comprehensive Attention National Policy (Brasil, 2008) by the Ministry of Health in Brazil in 2008 wasn't enough to insert them in the context of health care, being necessary to rethink the strategies of incorporation of the male population in these actions (Pereira et al., 2020).

According to Boltanski (2008), the concern that subjects deposit on their body grows when they rise in the social hierarchy, that is, in privileged social classes, including those with higher education, as the individuals investigated here. For the author it's in this group that we find the highest consumption of treatment products for body and the practice of a healthier lifestyle, including good nutrition and adherence to the practice of leisure-time physical activities. In fact, Lifchitz (1997), observed in Brazil changes in the food imagination of segments more economically favored with the emergence of what he called discourses around the "natural" which involved the proliferation of "good nutrition" and the choice of foods in natura. These actions according to Boltanski (2008) can be explained by the more reflective relationship with the body by these segments, according to the best educational level and the greater insertion of the group in occupations of intellectual nature. Besides, for Sobal (1991) the material condition of life of the group allows access to more suitable food for maintaining health and the practice of physical activities. To the extent that such social groups normally assume prestigious occupations and enjoy greater flexibility of hours and autonomy, there would be, therefore, a greater tendency for the incorporation of such behaviors. Inversely, according to Boltanski (2008), in the lower classes, including those with less education, the attention to the body may be less frequent. Particularly in this group, the use of the body can comprise a more utilitarian view, due to the importance of physical strength in the occupations performed. Within this perspective, for the working classes the body can presente itself as a condition for the production of work. In everyday struggle for daily survival, with hard and long working hours, the body tends not to be perceived in its entirely (Ferreira and Magalhães, 2006).

According to Bourdieu (1984), by eating habits we can get significant clues about class and income cleavages. In the author's mind, the tastes of luxury that comprise the selection of more refined food and preparations are linked to greater choice of social groups. In the lower classes, tastes would be presented as tastes of needs because for this group there would be no margin for healthy food choices. The social condition would determine, to a certain extent, the choice for an unhealthy diet and this, when combined with less physical activity, would contribute to an increase in BMI and overweight among the poorest individuals.

\section{Final Considerations}

The results indicate that, the perception of healthy eating is marked by social and gender issues but also by the adoption of another healthy behavior - the practice of activity. Moreover, perceiving nutrition as unhealthy may correspond to 
higher BMI values. The male universe, as well as those with less education, is a relevant field for researching and carrying out actions in the area of food and nutrition. Such researches can contribute to the reorganization of health actions based on the adoption of strategies that take into account multiple health behaviors, expanding the dialogue with specific segments, including younger and less educated men.

In the final analysis, some limitations of this study relate to possible biases due to the irregular number of participants, with the predominance of the female population over the male, and the use of convenience samples. However, given the multicentric nature of the study with countries on different continents, this was the sample design that made it possible to conduct it. In addition, such limitations were minimized by the high number of study participants.

\section{Acknowledgments}

This work is supported by national funds through FCT-Foundation for Science and Technology, IP, under the project Ref $^{a}$ UIDB / 00681/2020. Moreover, we would like to thank the Polytechnic Institute of Viseu for its support. This work was also carried out by the multinational center EATMOT of CI \& DETS Research Center (Polytechnic Institute of Viseu, Portugal) with the reference PROJ / CI \& DETS / CGD / 0012.

\section{References}

Asif, M., Xuhui, W., Nasiri. A., \& Ayyub, S. (2018). Determinant factors influencing organic food purchase intention and the moderating role of awareness: a comparative analysis. Food Quality and Preference, 3, 144-150.

Bartels, J., \& Hoogendam, K. (2011). The role of social identity and atitudes towards sustainability brands in purchasing behaviors for organic products. $J$. Brand Manag, 18, 697-708.

Bastos, T. F., Alves, M. C. G. P., Barros, M. B. de A., \& Cesar, L. G. C. (2012). Saúde do homem: um estudo de base populacional sobre as desigualdades sociais. Cadernos de Saúde Pública, 28(11), 2133-2142.

Baudrillard, J. (2010). A sociedade de consumo. Editor/a 70.

Baumann, Z. (2000). Em busca da política. Jorge Zahar.

Boaventura, G. F. (2013). Corpos perfumados: os homens em anúncios da revista Men's Health. Dissertação de Mestrado. Rio de Janeiro: Universidade Estadual do Rio de Janeiro.

Boltanski, L. (2008). As classes sociais e o corpo. Paz e Terra.

Bourdieu, P. (1984). La Distinction: a Social Critique of the Judgement of Taste. Harvard University Press, Cambridge, USA.

Bourdieu, P. (1999). A dominação masculina. Bertrand Brasil.

Brasil. Ministério da Saúde. (2008). Política Nacional de Atenção Integral à Saúde do Homem: princípios e diretrizes. Brasília: Ministério da Saúde.

Brasil, Ministério da Saúde. (2020). Banco de dados do Sistema Único de Saúde - DATASUS, Informações de Saúde, Mortalidade. www.datasus.gov.br

Brasil. Ministério da Saúde. Secretaria de Atenção à Saúde. Departamento de Atenção Básica (2014). Guia alimentar para a população brasileira. Ministério da Saúde, Secretaria de Atenção à Saúde, Departamento de Atenção Básica. Brasília: Ministério da Saúde.

Brasil. Ministério da Saúde. Universidade Federal de Minas Gerais (2016). Instrutivo: metodologia de trabalho em grupos para ações de alimentação e nutrição na atenção básica. Ministério da Saúde, Universidade Federal de Minas Gerais. Brasília: Ministério da Saúde.

Cavalcanti, J. R. D. (2014). Assistência integral a saúde do homem: necessidades, obstáculos e estratégias de enfrentamento. Esc. Anna Nery, 18(4), 628-634.

Costa, I., Gill, P. R., Morda, R., \& Ali, L. (2019). More than a diet: a qualitative investigation of young vegan women's relationship to food. Appetite, 105, $143-58$.

Eyken, E. B. B., Dell'Orto, V., \& Moraes, C. L. (2009). Prevalência de fatores de risco para doenças cardiovasculares entre homens de uma população urbana do Sudeste do Brasil. Cad. Saúde Pública, 25(1), 11-123.

Ferrão, A. C., Guine, R. P. F., Correia, P. M. R., Ferreira, M., Duarte, J., \& Lima, J. (2019). Desenvolvimento de um questionário para avaliar os determinantes das escolhas alimentares das pessoas. Curr. Nutr. Food Sci, 15, 281-295. 
Research, Society and Development, v. 10, n. 2, e50110212601, 2021 (CC BY 4.0) | ISSN 2525-3409 | DOI: http://dx.doi.org/10.33448/rsd-v10i2.12601

Ferreira, F. R. (2011). Ciência, arte e cultura no corpo: a construção de sentidos sobre o corpo a partir das cirurgias plásticas. CRV.

Ferreira, V. A., \& Magalhães, R. (2006). O corpo cúmplice da vida: considerações a partir dos depoimentos de mulheres obesas de uma favela carioca. Ciência \& Saúde Coletiva, 11 (2), 483-490.

Fischler C., \& Masson E. (2010). Comer: a alimentação de franceses, outros europeus e americanos. Editora Senac.

Goldenberg, M. (2002). Nu \& vestido. Record.

Goldenberg, M. (2004). De perto ninguém é normal. Record.

Gombi-Vaca, M. F., Horta, P. M., Hassan, B. K., Rocha, T. F. da, Skov, L. R., \& Verly-Jr, E. (2017). Perception of food consumed at home and dietary intake: a nationwide study from Brazil. Appetite, (116), 487-492.

Gomes, R. (2011). Saúde do homem em debate. Fiocruz.

Guiné, R. P. F., Bartkiene, E., Szücs, V., Tarcea, M., Ljubičić, M., Černelič-Bizjak, M., Isoldi, K., El-Kenawy, A., Ferreira, A. V., Straumite, E., Korzeniowska, M., Vittadini, E., Leal, M., Frez-Muñoz, L., Papageorgiou, M., Djekić, I., Ferreira, M., Correia, P., Cardoso, A. P., \& Duarte, J. (2020). Estudo sobre Determinantes da Escolha de Alimentos Segundo Seis Tipos de Motivações de Condicionamento em uma Amostra de 11.960 Participantes. Foods, (9), 888-92.

Hoek, A. C., Pearson, D., James, S. W., Lawrence, M. A., \& Friel, S. (2017). Shrinking food impression: a qualitative study on consumer perceptions, experiences and attitudes towards healthy and ecological eating behaviors. Apetite, 108, 117-131.

Ilana, G., Raskind, R. C., Woodruff, D., Ballard, S., Cherry, S., Daniel, R., Haardörfer, M., \& Kegler, C. (2017). Decision-making processes shaping the home food environments of young adult women with and without children, Appetite, 113, 124-133.

Irianto, H. (2015). Consumer attitude and intention towards the purchase of organic foods: an extension of the theory of planned behavior from a gender perspective. Int. J.Manag. Econ. Soc. Sci, 4(1), 17- 31.

Jaime, P. C. (2015). Prevalência e distribuição sociodemográfica de marcadores de alimentação saudável, Pesquisa Nacional de Saúde, Brasil 2013. Epidemiol. Serv. Saúde [online], 24(2), 267-276.

Lifschitz, J. (1997). Alimentação e cultura: em torno ao natural. PHYSIS: Revista Saúde Coletiva, 7(2), 69-83.

Lindemann, I. L., Oliveira, R. R., \& Mendoza-Sassi, R. A. (2016). Dificuldades para alimentação saudável entre usuários da atenção básica em saúde e fatores associados. Ciênc. saúde coletiva [online], 21, 599-610.

Lins, A. P. M., Sichieri, R, Coutinho, W. F., Ramos, E. G., Peixoto, M. V. M, \& Fonseca, V. M. (2013). Alimentação saudável, escolaridade e excesso de peso entre mulheres de baixa renda. Cien Saud Col., 18(2), 357-366.

Lipovetsky, G. (2002). O império do efêmero: a moda e seu destino nas sociedades modernas. Companhia da Letras.

Machado, K. P., Vaz, J. dos S., \& Mendonza-Sassi, R. A. (2020). Autopercepção positiva da alimentação: um estudo de base populacional no extremo sul do Brasil. Epidemiologia e Serviço de Saúde, 28(3), 1-14.

Ministério da Saúde. Secretaria de atenção à Saúde. Departamento de Atenção Básica. (1999). Política Nacional de Alimentação e Nutrição. Ministério da Saúde, Secretaria de Atenção a Saúde, Departamento de Atenção Básica. Brasília: Ministério da Saúde.

Ministério da Saúde. Secretaria de atenção à Saúde. Departamento de Atenção Básica. (2012). Política Nacional de Alimentação e Nutrição. $2^{a}$ Ed. Ministério da Saúde, Secretaria de Atenção a Saúde, Departamento de Atenção Básica. Brasilia: Ministério da Saúde.

Moura, E. C. (2014). Atenção à saúde dos homens no âmbito da Estratégia Saúde da Família. Ciência \& Saúde Coletiva, 19(2), 429-438.

Nagaraj, S. (2021). Role of consumer health consciousness, food safety \&amp, attitude on organic food purchase in emerging market: a serial mediation model, Journ of Retail and Consum Serv, 59.

Pereira, A. S. (2018). Metodologia de pesquisa científica. Rio Grande do Sul: Universidade Federal de Santa Maria.

Pereira, J., Klein, C., \& Meyer, D. E. (2020). PNAISH: uma análise de sua dimensão educativa na perspectiva de gênero. Saúde e Sociedade, 28(2), 132-146.

Reichert, F. F., Loch, M. R., \& Capilheira, M.F. (2012). Autopercepção de saúde em adolescentes, adultos e idosos. Ciencia e Saúde Coletiva, 17(12), 335362.

Rozin, P. (1980). Selection of human food: why do we know so little and what can we do about it? International Journal of Obesity, $4,333-337$.

Santos, T., Julián, C., Vincenzi, S., De Andrade, D., Slater, B., Assis, M. de, \& Moreno, L. (2020). Uma nova medida de motivação para a saúde influenciando as escolhas alimentares e sua associação com a ingestão de alimentos e biomarcadores nutricionais em adolescentes europeus. Nutr Saud Publ, 1-11.

Sobal, J. (1991). Obesity and socioeconomic status - a framework for examining relationship between physical and social variables. Medical Anthropology, 13(3), 231-247.

Tabassum, A., \& Jabir A. (2020). Factors affecting the consumers' willingness to pay for health and wellness food products. Journal of Agriculture and Food Research, 2. 
Research, Society and Development, v. 10, n. 2, e50110212601, 2021

(CC BY 4.0) | ISSN 2525-3409 | DOI: http://dx.doi.org/10.33448/rsd-v10i2.12601

Toledo, M. T. T., Abreu, M. N., \& Lopes, A. C. S. (2013). Adesão a modos saudáveis de vida mediante aconselhamento por profissionais de saúde. Revista Saúde Pública, 47(3), 540-548.

World Health Organization. (2018). Global Nutrition Policy Review 2016-2017: Country Progress in Creating Favorable Policy Environments for Promoting Healthy Diets and Nutrition. Geneva: WHO.

World Health Organization. (2020). The top 10 causes of death. Geneva: WHO.

Yadav, R., \& Pathak, G. S. (2016). Intention to purchase organic food among young consumers: evidences from a developing nation. Appetite, 96, 122-128. 